\title{
EXPERIMENTAL ENVENOMATION WITH Crotalus durissus terrificus VENOM IN DOGS TREATED WITH ANTIOPHIDIC SERUM - PART I: CLINICAL EVALUATION, HEMATOLOGY AND MYELOGRAM
}

\author{
NOGUEIRA R. M. B. (1), SAKATE M. (2), SANGIORGIO F. (1),
}

LAPOSY C. B. (3), MELERO M. (1)

(1) Department of Small Animals, Medical Clinic, University of Western São Paulo, UNOESTE, Presidente Prudente, São Paulo State, Brazil; (2) Department of Small Animals, Medical Clinic, School of Veterinary Medicine and Animal Husbandry, São Paulo State University, UNESP, Botucatu, São Paulo State, Brazil; (3) Department of Clinical Pathology, UNOESTE, Presidente Prudente, São Paulo State, Brazil.

ABSTRACT: The present study aimed at evaluating clinical and laboratory aspects during experimental envenomation by Crotalus durissus terrificus in dogs treated with antiophidic serum. Twenty-one dogs were divided into three groups of seven animals each. Group I received 1mg/kg venom (sc); Group II received 1mg/kg venom (sc), $50 \mathrm{mg}$ antiophidic serum (iv), and fluid therapy including $0.9 \% \mathrm{NaCl}$ solution (iv); and Group III received $1 \mathrm{mg} / \mathrm{kg}$ venom (sc), 50mg antiophidic serum (iv), and fluid therapy including $0.9 \% \mathrm{NaCl}$ solution containing sodium bicarbonate diluted to the dose of $4 \mathrm{mEq} / \mathrm{kg}$. The clinical signs of ataxia, sedation, flaccid paralysis, mydriasis, eyeball paralysis, mandible ptosis, sialorrhea, vomiting and diarrhea observed in the dogs were very similar to those observed in humans. The decrease in hemoglobin, hematocrit, erythrocyte, platelet and fibrinogen levels, prolongation of clotting time, prothrombin time (PT) and activated partial thromboplastin time (APTT), as well as hypocellularity in the bone marrow characterized anemia, thrombocytopenia and blood incoagulability, as well as hypofibrinogenemia and decreased bone-marrow activity. Important bleeding was not observed. Increased numbers of leukocytes and neutrophils and decreased numbers of lymphocytes and eosinophils characterized an acute inflammatory response and stress caused by generalized pain. The employed antiophidic serum was effective and all animals survived.

KEY WORDS: Crotalus durissus terrificus, dogs, clinical aspects, laboratory aspects.

CONFLICTS OF INTEREST: There is no conflict.

CORRESPONDENCE TO:

ROSA MARIA BARILLI NOGUEIRA, Rua Santo Brugnoli, 249, 19025-160, Presidente Prudente, São Paulo, Brasil. Email:noballi@ig.com.br.

\section{INTRODUCTION}


R. M. B. Nogueira et al. EXPERIMENTAL ENVENOMATION WITH Crotalus durissus terrificus VENOM IN DOGS TREATED WITH ANTIOPHIDIC SERUM - PART I: CLINICAL EVALUATION, HEMATOLOGY AND MYELOGRAM. J. Venom. Anim. Toxins incl. Trop. Dis., 2007, 13, 4, p. 801

The genus Crotalus of the family Crotalidae and its subspecies Crotalus durissus terrificus are the second most important cause of accidents in Brazil. Crotalus snakes are considered more venomous than snakes of the Bothrops genus (10). The genus Crotalus is of great importance as the venom of its members causes severe clinical aspects and most of the times can be fatal when treatment with specific anti-serum is not quickly instituted $(10,12)$. Crotalus venom is constituted of several fractions including the following toxins: crotoxin, crotamine, giroxin, and convulxin $(9,30,31)$. It has three main actions: neurotoxic $(11)$, myotoxic $(3,4)$ and hemolytic $(33)$. The major complications observed in Crotalus envenomation are acute renal failure and tubular necrosis $(23,28,33)$.

\section{MATERIALS AND METHODS}

The present experiment was approved by the Ethics Committee of University of Western São Paulo, UNOESTE, Presidente Prudente, Brazil.

Twenty-one dogs (1-4 years old; no defined breed; 4-15kg) from the Central Kennel of UNOESTE were used. Based on a complete physical examination and laboratory tests, animals that presented normal values were selected (22). They were kept in individual stalls at the kennel of the Veterinary Hospital of UNOESTE and received water and food ad libitum.

Animals were divided into three groups of seven animals each, Group I: animals inoculated with crotalic venom $(1 \mathrm{mg} / \mathrm{kg})$; Group II: animals inoculated with crotalic venom $(1 \mathrm{mg} / \mathrm{kg})$ and treated with antiophidic serum $(50 \mathrm{mg})$ and fluid therapy including $0.9 \% \mathrm{NaCl}$ solution $6 \mathrm{~h}$ after venom inoculation (AV); Group III: animals inoculated with crotalic venom $(1 \mathrm{mg} / \mathrm{kg})$, and treated with antiophidic serum $(50 \mathrm{mg})$ and fluid therapy including $0.9 \% \mathrm{NaCl}$ solution containing sodium bicarbonate diluted to the dose of $4 \mathrm{mEq} / \mathrm{Kg} 6 \mathrm{~h}$ after venom inoculation (AV).

Antiophidic serum (bothropic-crotalic) was from Vencofarma Laboratory (serum sample 001/03); each flask of $10 \mathrm{ml}$ serum neutralizes $10 \mathrm{mg}$ crotalic venom.

Lyophilized crotalic venom supplied by the Center for the Study of Venoms and Venomous Animals, CEVAP, UNESP, Brazil, was reconstituted in sterile saline solution and subcutaneously inoculated, at the dose of $1 \mathrm{mg} / \mathrm{kg}$ body weight, into the 
R. M. B. Nogueira et al. EXPERIMENTAL ENVENOMATION WITH Crotalus durissus terrificus VENOM IN DOGS TREATED WITH ANTIOPHIDIC SERUM - PART I: CLINICAL EVALUATION, HEMATOLOGY AND MYELOGRAM. J. Venom. Anim. Toxins incl. Trop. Dis., 2007, 13, 4, p. 802

lateral surface of the animals' thigh; antiophidic serum was intravenously administered 6h after venom inoculation (AV).

Clinical evaluation included heart and breathing frequencies, pulse rate, temperature, locomotion, sedation and muscle rigidity degrees, pupil diameter, sialorrhea, vomit and diarrhea. Laboratory tests included blood cell count (blood samples were collected by jugular vein puncture using Vacutainer test tubes for hemogram), clotting time (19), coagulogram (blood samples were collected by jugular vein puncture using Vacutainer tubes containing citrate) and myelogram (samples were collected by iliac crest puncture using a special needle for bone marrow biopsy and aspiration) $(1,7)$ at different moments according to table 1.

Table 1. Moments (M) of clinical evaluation and laboratory tests - blood cell count, clotting time, coagulogram and myelogram.

\begin{tabular}{|c|c|c|c|c|c|c|}
\hline & M0 & M1 & M2 & M3 & M4 & M5 \\
\hline Clinical evaluation & Control & $6 \mathrm{~h} \mathrm{AV}$ & $24 \mathrm{~h} \mathrm{AV}$ & $48 \mathrm{~h}$ AV & $72 \mathrm{~h} \mathrm{AV}$ & $144 \mathrm{~h} \mathrm{AV}$ \\
\hline Blood cell count & Control & $6 \mathrm{~h} \mathrm{AV}$ & $24 \mathrm{~h} \mathrm{AV}$ & $48 \mathrm{~h}$ AV & $72 \mathrm{~h} \mathrm{AV}$ & $144 \mathrm{~h} \mathrm{AV}$ \\
\hline Clotting time & Control & $1 \mathrm{~h} \mathrm{AV}$ & $24 \mathrm{~h} \mathrm{AV}$ & - & - & - \\
\hline Coagulogram & Control & $2 \mathrm{~h} \mathrm{AV}$ & $6 \mathrm{~h} \mathrm{AV}$ & $24 \mathrm{~h}$ AV & $48 \mathrm{~h}$ AV & - \\
\hline Myelogram & Control & $6 \mathrm{~h} \mathrm{AV}$ & $72 \mathrm{~h} \mathrm{AV}$ & - & - & - \\
\hline
\end{tabular}

AV: after venom inoculation; Antiophidic serum was administered $6 \mathrm{~h}$ after venom administration.

\section{Statistical analysis}

Each variable was studied by analysis of repeated measures or profiles (25) of differences between each evaluation moment and the control moment in Groups I, II and III throughout the experiment.

For variables whose results were given by scores, groups were compared at every moment using Kruskal-Wallis non-parametric test, and the effect of moments on each group was compared using Friedman non-parametric test $(25,35)$. A significance level of $p<0.05$ was adopted. 
R. M. B. Nogueira et al. EXPERIMENTAL ENVENOMATION WITH Crotalus durissus terrificus VENOM IN DOGS TREATED WITH ANTIOPHIDIC SERUM - PART I: CLINICAL EVALUATION, HEMATOLOGY AND MYELOGRAM. J. Venom. Anim. Toxins incl. Trop. Dis., 2007, 13, 4, p. 803

\section{RESULTS AND DISCUSSION}

\section{Clinical evaluation}

Discreet edema and discomfort was observed at the venom inoculation sites in all groups.

Animals of all three groups presented ataxia and sedation at $M 1$, which persisted until $72 \mathrm{~h}$ AV in Groups II and III and until 144h AV in Group I.

Flaccid paralysis of facial muscles, generalized myalgia, eyeball paralysis, mandible ptosis, and phonation and deglutition difficulties were observed at M1 $(p<0.05)$ in Groups I and III, which returned to normality at M2. The venom has effects on the central nervous system, compromising the III (oculomotor), IV (trochlear), VI (abducent) and XI (accessory) cranial nerves and peripheral nervous system (8, 16, $29,30)$. The observed clinical alterations are attributed to the venom neurotoxic (2, 20) and myotoxic activities $(3,6)$.

Temperature, breathing and heart frequencies and pulse rate did not show any significant difference among moments for each group nor among groups for each moment.

Moderate sialorrhea was observed in $28.57 \%$ animals of Groups I and II and in $42.86 \%$ animals of Group III until 24h AV. Vomiting episodes occurred in $42.86 \%$ animals of Groups I and in 28.57\% animals of Group III. The decrease in the incidence of vomiting episodes in animals of Group III was probably due to the administration of bicarbonate.

Diarrhea occurred in $28.57 \%$ animals of Groups I and III and in $14.28 \%$ animals of Group II.

Mydriasis, bilaterally responsive to light, occurred in $57.14 \%$ animals of Group I and in $42.86 \%$ animals of Groups I and III from M1 to M3

In a general manner, animals of Group II demonstrated less clinical alterations or returned to the initial normal values, compared with animals of Groups I and III.

\section{Blood cell count}

A significant decrease was observed $(p<0.05)$ in the number of red blood cells in Group II at M2 and in Groups I, II and III at M3, M4 and M5, respectively, prevailing normocytic normochromic anemia.

The decrease in erythrocyte, hemoglobin and hematocrit levels can be attributed to the venom hemolytic action verified in vitro $(6,15,18,21,24,29,33)$. 
R. M. B. Nogueira et al. EXPERIMENTAL ENVENOMATION WITH Crotalus durissus terrificus VENOM IN DOGS TREATED WITH ANTIOPHIDIC SERUM - PART I: CLINICAL EVALUATION, HEMATOLOGY AND MYELOGRAM. J. Venom. Anim. Toxins incl. Trop. Dis., 2007, 13, 4, p. 804

Leukocytosis with neutrophilia was observed at M1 in Group III and at M2 in Groups I and II, which returned to normal values at M3 in Groups II and III and at M4 in Group I.

Leukocytosis with neutrophilia can be caused by the interaction between the crotalic venom and the animal organism, inducing a typical acute-phase response with release of catecholamines, cellular mediators and humor, besides serum chemotactic factors. Leukocytosis with neutrophilia has also been reported in the initial phase of crotalic envenomation in humans $(20,26,32,34)$ and animals $(14,27,29,36,38)$.

The decrease in the number of lymphocytes and eosinophils, although not significant and within normal values for the species, characterized stress probably caused by the pain in all three groups at M1 $(20,27,36)$.

Decreased platelet numbers were noticed in all three groups at $\mathrm{M} 2$ and $\mathrm{M} 3$, relative to the control moment.

\section{Clotting time}

Evaluation of the clotting time showed a significant alteration in all thee groups at M1. Eighteen hours after the antiophidic serum administration, clotting time returned to normality in animals of Groups II and III but kept high in animals of Group I $(13,29$, 37).

Alteration in the clotting time is due to the venom fraction named "thrombin-like", capable of converting fibrinogen into fibrin, leading the patient to hypofibrinogenemia, which culminates with prolongation of clotting time $(13,37,29)$.

Recently, clinical and laboratory investigations were carried out in 24 patients bitten by Crotalus durissus revealing hypofibrinogenemia as well as secondary fibrinolytic activation. Some of these patients also presented consumption of coagulation factors $\mathrm{V}$ and VIII, as well as generation of intravascular thrombin, which could not be explained by the thrombin-like activity of this venom (32).

\section{Coagulogram}

Prothrombin time (PT) and activated partial thromboplastin time (APTT) significantly prolonged at M1 and M2 in animals of all three groups. At M3 and M4, animals of Group I continued presenting significant PT and APTT prolongation.

Prolonged PT and APTT and decreased fibrinogen levels suggest a possible compromising of other factors of the extrinsic or intrinsic pathway and factors that are common to both pathways of the coagulation cascade $(5,15,16,17,36)$. 
R. M. B. Nogueira et al. EXPERIMENTAL ENVENOMATION WITH Crotalus durissus terrificus VENOM IN DOGS TREATED WITH ANTIOPHIDIC SERUM - PART I: CLINICAL EVALUATION, HEMATOLOGY AND MYELOGRAM. J. Venom. Anim. Toxins incl. Trop. Dis., 2007, 13, 4, p. 805

\section{Myelogram}

Normal cells were observed at control moment (Figure 1A) and at M2 (Figure $1 \mathrm{C}$ ) with conserved maturation and normal mitoses for all cell series, including erythroid and myeloid series. At M1, bone marrow was hypocellular in all three groups (Figure 1B), together with relative hypoplasia of the erythroid series in all three groups, absolute hyperplasia of the myeloid series in Group I and relative hyperplasia in Groups II and III.

A decrease in erythropoiesis and granulopoiesis, intensified by the increased myeloid:erythroid (M:E) ratio, was observed. An integrated analysis with peripheral blood showed inflammation, characterized in blood cell count as an increase in the numbers of leukocytes and segmented neutrophils (19).

There were not alterations in the megakaryocytic series for all three groups, characterizing normality.

Although megakaryocyte count was not carried out, megakaryocytic hypoplasia was suggested at M1. 

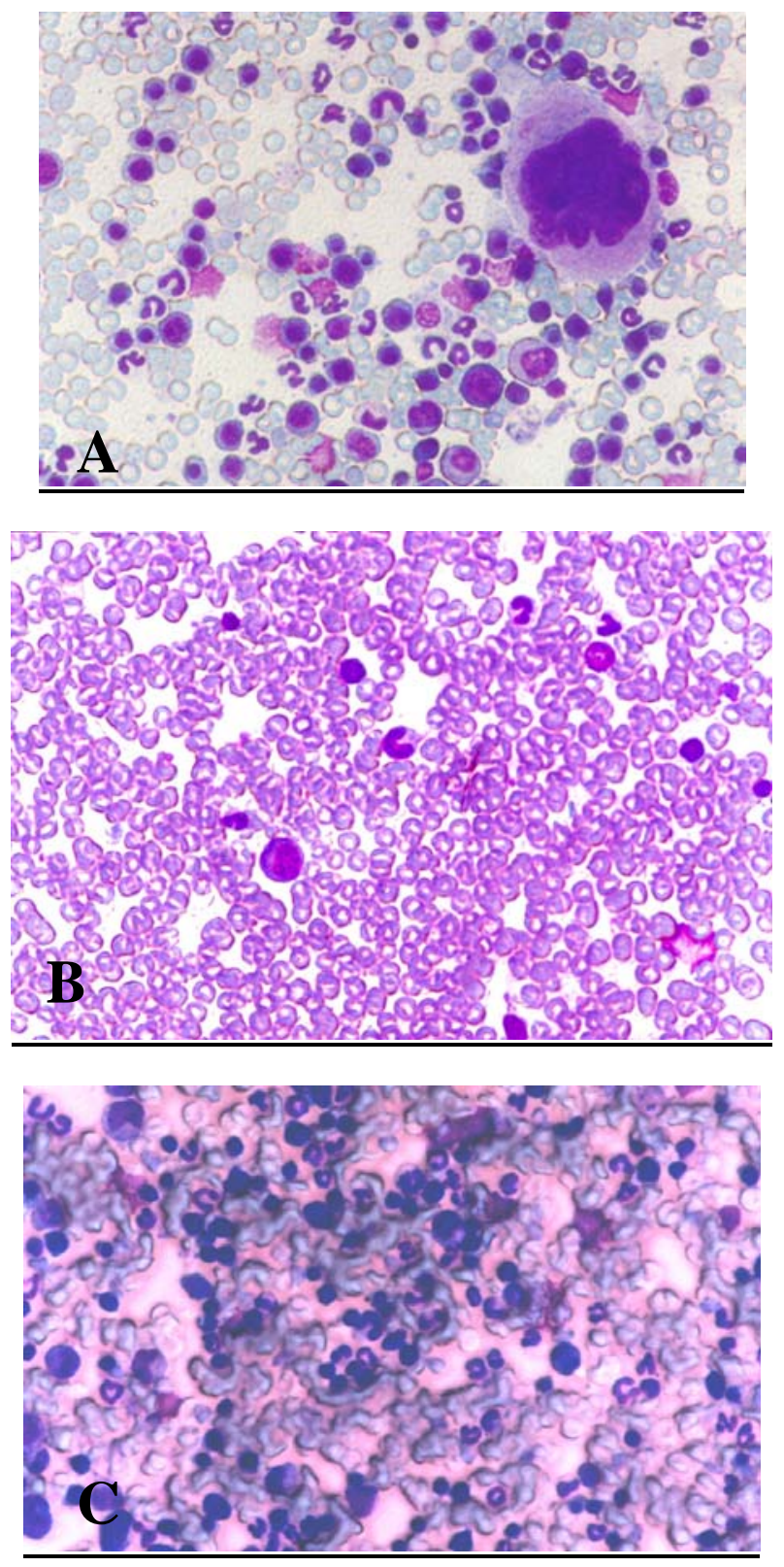

Figure 1. A: Bone marrow with normal cells at control moment (Leishman stain 400x); B: Hypocellular bone marrow $6 \mathrm{~h}$ after crotalic venom administration (Leishman stain - 400x); C: Bone marrow with normal cells $72 \mathrm{~h}$ after crotalic venom administration (Leishman stain - 100x).

\section{CONCLUSION}

The observed clinical alterations, such as generalized pain, discreet edema, generalized flaccid paralysis, eyeball paralysis, mydriasis, mandible ptosis, sialorrhea, vomiting and diarrhea, are very similar to those caused by crotalic envenomation in humans.

There was a decrease in erythrocyte, hemoglobin and hematocrit levels, characterizing anemia as a consequence of the venom hemolytic action. 
R. M. B. Nogueira et al. EXPERIMENTAL ENVENOMATION WITH Crotalus durissus terrificus VENOM IN DOGS TREATED WITH ANTIOPHIDIC SERUM - PART I: CLINICAL EVALUATION, HEMATOLOGY AND MYELOGRAM. J. Venom. Anim. Toxins incl. Trop. Dis., 2007, 13, 4, p. 807

Leukocytosis with neutrophilia occurred as a typical inflammatory acute-phase response and due to the inflammation at the venom inoculation site.

The decrease in the number of lymphocytes and eosinophils characterized stress mainly caused by the generalized pain.

Crotalic venom caused a decrease in platelet number, hypocellularity in the bone marrow, and a decrease in fibrinogen levels six hours after the venom inoculation. The decrease in fibrinogen levels justifies the prolonged prothrombin time and activated partial thromboplastin time.

Blood incoagulability was the most frequently observed laboratory alteration starting one hour after venom inoculation and returning to normality 18 hours after therapy using antiophidic serum.

Although blood incoagulability and thrombocytopenia were observed, there was not important bleeding.

The antiophidic serum therapy administered six hours after venom inoculation, was effective in preventing death and in restoring the animals' clinical conditions.

\section{ACKNOWLEDGEMENTS}

The authors are grateful to Master's Program at UNOESTE, for financial support; Master's Program of FMVZ-UNESP, Botucatu, for the assistance; Center for the Study of Venoms and Venomous Animals, CEVAP, UNESP, Botucatu; Clinical Laboratory and Pathological Anatomy Laboratory, Veterinary Hospital, UNOESTE; and Dr. Luzia Trinca, for the statistical analysis.

\section{REFERENCES}

1 ALENCAR NX., KOHAYAGAWA A., CAMPOS KCH., TAKAHIRA RK. Myelograma. Parte I: Indicações e colheita de material. Rev. Educ. Cont. CRMV-SP, 2002, 5, 15763.

2 AMARAL CFS., MAGALHÃES RA., REZENDE NA. Comprometimento respiratório secundário a acidente ofídico crotálico (Crotalus durissus). Rev. Inst. Med. Trop. São Paulo, 1991, 33, 251-5.

3 AZEVEDO-MARQUES MM., CUPO P., COIMBRA TM., HERING SE., ROSSI MA., LAURE CJ. Myonecrosis, myoglobinuria and acute renal failure induced by South American rattlesnake (Crotalus durissus terrificus) envenomation in Brazil. Toxicon, 1985, 23, 631-6. 
4 AZEVEDO-MARQUES MM., CUPO P., COIMBRA TM., HERING SE., ROSSI MA., OLIVEIRA JÁ. Mionecrose e insuficiência renal aguda mioglobinúrica após acidente crotálico. In: CONGRESSO DA SOCIEDADE BRASILEIRA DE MEDICINA TROPICAL, 18, Ribeirão Preto, 1982. Anais... Ribeirão Preto, 1982. p.12.

5 AZEVEDO-MARQUES MM., CUPO P., HERING SE. Acidentes por animais peçonhentos: serpentes peçonhentas. Medicina, 2003, 36, 480-9.

6 AZEVEDO-MARQUES MM., HERING SE., CUPO P. Evidence that Crotalus durissus terrificus (South American rattlesnake) envenomation in humans causes myolysis rather than hemolysis. Toxicon, 1987, 11, 1163-8.

7 BARKER RN. Anemia associated with immune responses. In: FELDMAN B., ZINKL J., JAIN NC. Eds. Schalm's Veterinary Hematology. 5.ed. Philadelphia: Lippincott Williams \& Wilkins, 2000. 1344p.

8 BARRAVIERA B., COELHO KYR., CURI PR., MEIRA DA. Liver dysfunction in patients bitten by Crotalus durissus terrificus (Laurenti, 1768) snakes in Botucatu (State of São Paulo-Brazil). Rev. Inst. Med. Trop. São Paulo, 1995, 37, 63-70.

9 BARRIO A. Gyroxin, a new neurotoxin of Crotalus durissus terrificus venom. Acta Physiol. Lat. Am., 1961, 11, 224-32.

10 BELLUOMINI HE. Conhecimentos sobre as serpentes brasileiras e medidas de prevenção de acidentes. Rev. Bras. Saúde Ocup., 1984, 12, 82-96.

11 BRASIL. Ministério da Saúde. Fundação Nacional de Saúde. Manual de diagnósticos e tratamento de acidentes por animais peçonhentos. 2.ed. Brasília, 2001. 131p.

12 BRAZIL OV., FARINA R., YOSHIDA L., OLIVEIRA VA. Pharmacology of crystalline crotoxin. 3. Cardiovascular and respiratory effects of crotoxin and Crotalus durissus terrificus venom. Mem. Inst. Butantan, 1966, 33, 993-1000.

13 BUCARETCHI F., HERRERA SRF., HYSLOP S., BARACAT ECE., VIEIRA RJ. Snakebites by Crotalus durissus ssp in children in Campinas, São Paulo, Brazil. Rev. Inst. Med. Trop. São Paulo, 2002, 44, 133-8.

14 COLLICCHIO RC., SAKATE M., BALARIN MRS., HATAKA A., KLEIN RP., VIANA L., NOGUEIRA FS. Relato de caso: alterações clínicas e laboratoriais conseqüentes à picada de cascavel (Crotalus durissus terrificus) em uma cadela gestante. Rev. Clín. Vet., 2002, 7, 45-8.

15 FURTADO MFD., SANTOS MC., KAMIGUTI AS. Age-related biological activity of South American rattlesnake (Crotalus durissus terrificus) venom. J. Venom. Anim. Toxins incl. Trop. Dis., 2003, 9, 186-201. 
R. M. B. Nogueira et al. EXPERIMENTAL ENVENOMATION WITH Crotalus durissus terrificus VENOM IN DOGS TREATED WITH ANTIOPHIDIC SERUM - PART I: CLINICAL EVALUATION, HEMATOLOGY AND MYELOGRAM. J. Venom. Anim. Toxins incl. Trop. Dis., 2007, 13, 4, p. 809

16 GARCIA-NAVARRO CEK., PACHALY JR. Manual de hematologia. 1.ed. São Paulo: Varela, 1994. 169p.

17 GREEN RA. Hemostasis and disorder of coagulation. Vet. Clin. North Am. Small Anim. Pract., 1981, 11, 289-319.

18 GOMEZ-LEIVA MA., PAZOS-SANOU L. A simple method for the measurement of the hemolytic power of crude snake venoms. Rev. Biol. Trop., 1983, 31, 341-2.

19 JAIN NC. Essentials of Veterinary hematology. Philadelphia: Lea \& Febiger, 1993. $417 p$.

20 JORGE MT., RIBEIRO LA. Epidemiologia e quadro clínico do acidente por cascavel sul-americana (Crotalus durissus terrificus). Rev. Inst. Med. Trop. São Paulo, 1992, 34, 347-54.

21 KAMIGUTI AS., CARDOSO JLC. Review article: Haemostatic changes caused by the venoms of South American snakes. Toxicon, 1989, 27, 955-63.

22 MCCURNIN DM., POOFFENBARGER EM. Small animal physical diagnosis and clinical procedures. Phyladelphia: Saunders, 1991. 222p.

23 MAGALHÃES RA., RIBEIRO MMF., REZENDE NA., AMARAL CFS. Rabdomiólise secundaria a acidente crotálico (Crotalus durissus terrificus). Rev. Inst. Med. Trop. São Paulo, 1986, 28, 228-33.

24 MARTINEZ-CADILLO CE., BONILLA FC., ZAVALETA A. Actividad hemolítica de venenos de serpientes de los géneros Bothrops, Lachesis, Crotalus y Micrurus (Serpentes: Viperidae y Elapidae). Rev. Biol. Trop., 1991, 39, 311-4.

25 MORRISON DF. Multivariate statistical methods. New York: McGraw-Hill, 1990. 450 .

26 MOURA-GONCALVES J., VIEIRA A. Estudo sobre o veneno de serpentes brasileiras. I: Analise eletroforética. An. Acad. Bras. Ciênc., 1950, 22, 141-50.

27 NISHIOKA SA., JORGE MT., SILVEIRA PVP., RIBEIRO LA. South American rattlesnake bite and soft-tissue infection: report a case. Rev. Soc. Bras. Med. Trop., 2000, 33, 401-2.

28 NOGUEIRA RMB., SAKATE M. Clinical and hematological alterations in dogs during experimental envenomation with Crotalus durissus terrificus venom and treated with antiophidic serum. J. Venom. Anim. Toxins incl. Trop. Dis., 2006, 12, 285-96.

29 PINHO FMO., PEREIRA ID. Ofidismo. Rev. Assoc. Med. Bras., 2001, 47, 24-9.

30 PRADO-FRANCESCHI J., BRAZIL OV. Convulxin, a new toxin from the venom of the South American rattlesnake Crotalus durissus terrificus. Toxicon, 1981, 19, 87587. 
31 ROODT AR., DOLAB JA., SEGRE L. Fisiopatologia y diagnóstico del ataque por serpientes venenosas: una breve actualización. Rev. Med. Vet., 1996, 77, 64-71.

32 ROSENFELD G. Acidentes por animais peçonhentos: serpentes, aranhas, escorpiões. In: VERONESI R. Ed. Doenças infecciosas e parasitárias. 8.ed. Rio de Janeiro: Guanabara Koogan, 1991, 951-62.

33 ROSENFELD G., KELEN EMA., NUDEL F. Hemolytic activity of animal venoms. I: Classification in different types and activities. Mem. Inst. Butantan, 1960-62, 30, 10316.

34 SANO-MARTINS I., TOMY SC., CAMPOLINA D., DIAS MB., CASTRO SC., AMARAL CFS., REZENDE NA., KAMIGUTI AS., WARRELL DA., THEAKSTON RDG. Coagulopathy following lethal and non-lethal envenoming of humans by the South American rattlesnake (Crotalus durissus) in Brazil. Q. J. Med., 2001, 94, 551-9. 35 SIEGEL S. Estatística não paramétrica: para as ciências do comportamento. São Paulo: McGraw-Hill, 1975. 350p.

36 SOERENSEN B., NETO LZ., OLIVEIRA AM., SANTOS RV., MESSIAS CV. Aspecto clínico e laboratorial do envenenamento botrópico e crotálico em bovinos. Unimar Ciênc., 1995, 4, 28-33.

37 SOUSA-E-SILVA MCC., TOMY SC., TAVARES FL., NAVAJAS L., LARSSON MHMA., LUCAS SRR., KOGIKA MM., SANO-MARTINS I. Hematological, hemostatic and clinical chemistry disturbances induced by Crotalus durissus terrificus snake venom in dogs. Human Exp. Toxicol., 2003, 22, 491-500.

38 THOMAZINI IA., BARRAVIERA B. Alterações hematológicas nos acidentes por animais peçonhentos. In: BARRAVIERA B. Ed. Venenos animais: uma visão integrada. Rio de Janeiro: EPUC, 1994, 81-96. 